\title{
Pengembangan perangkat pembelajaran klasifikasi hewan berbasis guided inquiry dengan sumber belajar potensi alam kebun teh Wonosari untuk mengembangkan sikap ilmiah, keterampilan proses sains, dan pemahaman konsep siswa SMP Negeri 3 Lawang
}

\author{
Anandayu Dwi Arini, Ibrohim*, dan Sueb \\ Universitas Negeri Malang, Jl. Semarang No. 5 Malang, Jawa Timur, Indonesia \\ *Penulis korespondensi, Surel: ibrohim.fmipa@um.ac.id
}

Paper received: 02-01-2021; revised: 15-01-2021; accepted: 30-01-2021

\begin{abstract}
The problems found in science learning at SMPN 3 Lawang that the material selected for the classification of animals using the model of inquiry but have not implemented all the syntax inquiry and there has not used natural potentials as learning resource of biology. Related to that, the research has been done to make a product of guided inquiry learning device with learning resource Wonosari Tea Garden, and to know determine effectiveness of learning through assessment scientific attitude, science process skills, and comprehension concept. The research and development used 4D model that was conducted up to a develop step. The results of research and development has been delivered learning device 87.94 percent in very valid category, scientific attitude 85.30 percent in very high category, science process skills 81.93 percent in high category, comprehension concept 78.88 percent in high category, and learning device implementation 91.02 percent in very good category.
\end{abstract}

Keywords: learning device; guided inquiry; scientific attitude; comprehension concept

\begin{abstract}
Abstrak
Permasalahan yang ditemukan pada pembelajaran IPA di SMPN 3 Lawang bahwa pada materi klasifikasi hewan menggunakan model inquiry, namun belum melaksanakan semua sintaks inquiry serta kurang adanya pemanfaatan kompetensi alam Kebun Teh Wonosari sebagai sumber belajar biologi. Berkaitan dengan hal tersebut telah dilakukan penelitian yang bertujuan untuk menyajikan perangkat pembelajaran berbasis guided inquiry dengan sumber belajar Kebun Teh Wonosari dan mengetahui keefektifan perangkat pembelajaran melalui penilaian sikap ilmiah, keterampilan proses sains, pemahaman konsep. Metode penelitian dan pengembangan menggunakan model 4D yang dibatasi hingga tahap develop. Dari hasil penelitian dan pengembangan telah dihasilkan perangkat pembelajaran yang berkriteria sangat valid sebesar 87,94 persen, sikap ilmiah 85,30 persen dengan kriteria sangat tinggi, keterampilan proses sains 81,93 persen dengan kriteria tinggi, pemahaman konsep 78,88 persen dengan kriteria tinggi, serta keterlaksanaan perangkat pembelajaran berkriteria sangat baik 91,02 persen.
\end{abstract}

Kata kunci: perangkat pembelajaran; guided inquiry; sikap ilmiah, keterampilan proses sains; pemahaman konsep

\section{Pendahuluan}

Kurikulum 2013 didesain berdasarkan pada budaya dan karakter bangsa, berbasis peradaban, dan berbasis kompetensi. Salah satu karakteristik kurikulum 2013 yaitu sekolah merupakan bagian dari masyarakat yang memberikan pengalaman belajar terencana dimana peserta didik menerapkan apa yang dipelajari di sekolah ke masyarakat dan memanfaatkan masyarakat sebagai sumber belajar (Permendikbud No 68, 2013). Sejalan dengan hal tersebut, kekayaan sumber daya di Indonesia yang tinggi dapat dimanfaatkan ke dalam 
pembelajaran. Potensi alam dimanfaatkan sebagai sumber belajar sehingga peserta didik akan mengetahui potensi alam yang ada disekitarnya. Menurut Widowati (2012: 7), pemanfaatan lingkungan sekitar di dalam proses pembelajaran biologi akan lebih bermakna karena peserta didik dihadapkan pada peristiwa yang bersifat aktual dan alami yang dapat dipertanggungjawabkan kebenarannya.

Sasaran pembelajaran dalam Kurikulum 2013 mencakup pengembangan ranah sikap, keterampilan, dan pengetahuan yang dielaborasi untuk setiap satuan pendidikan. Ranah kompetensi tersebut diperoleh melalui pendekatan ilmiah yang diperkuat dengan penerapan pembelajaran salah satunya berbasis penyingkapan/penelitian (discovery/inquiry learning). Sanjaya (2011: 196) menyatakan bahwa model pembelajaran inquiry adalah rangkaian kegiatan pembelajaran yang menekankan pada proses berpikir secara kritis dan analitis untuk mencari dan menemukan sendiri jawaban dari suatu masalah yang dipertanyakan. Menyelidiki sesuatu berarti mencari informasi, menjadi ingin tahu, mengajukan pertanyaan, menyelidiki, dan mempelajari keterampilan yang akan membantu untuk menemukan penyelesaian dari suatu masalah (Lailiyah, 2007: 12).

Hasil observasi terhadap kondisi lingkungan di SMPN 3 Lawang bahwa lokasi sekolah dekat dengan Kebun Teh Wonosari. Kebun Teh Wonosari terdapat keanekaragaman serangga. Berdasarkan kondisi dan potensi di Kebun Teh Wonosari, materi klasifikasi makhluk hidup menjadi materi yang menarik untuk dibelajarkan melalui pembelajaran guided inquiry. Hal ini akan memfasilitasi siswa dalam memperoleh tiga ranah kompetensi seperti yang tertera pada Kurikulum 2013.

Kurikulum 2013 mencakup pengembangan sikap, keterampilan, dan pengetahuan. Berkaitan dengan karakteristik pembelajaran IPA maka kompetensi siswa yang diharapkan adalah sikap ilmiah, keterampilan proses sains, dan pemahaman konsep. Kartono (2012: 3) menyatakan sikap ilmiah adalah sikap yang harus ada pada diri seorang ilmuwan atau akademisi ketika menghadapi persoalan ilmiah. Pembelajaran sikap ilmiah menurut Fakhruddin et al. (2010: 19) diperlukan sikap rasa ingin tahu, bekerja sama secara terbuka, bekerja keras, bertanggung jawab, kepedulian, kedisplinan, dan kejujuran. Trianto (2010: 144) menyatakan keterampilan proses adalah keterampilan ilmiah yang terarah yang dapat digunakan untuk menemukan konsep atau prinsip. Pemahaman konsep adalah pemahaman sesuatu dengan pikiran, pemahaman yang dimaksud yaitu mampu menangkap arti serta mampu menjelaskan konsep (Wijayanti, 2010: 30).

Kompetensi siswa yang diharapkan terkait dengan kualitas pembelajaran yang dilakukan di kelas. Pembelajaran di SMPN 3 Lawang menggunakan Kurikulum 2013. Pada perangkat pembelajaran materi klasifikasi guru menggunakan metode inquiry namun belum menerapkan semua sintaks inquiry, pengamatan dan diskusi dengan media gambar makhluk hidup, buku Paket IPA, Lembar Kerja Siswa (LKS), dan handout. Isi LKS masih berupa pertanyaan dan belum menuntut kerja ilmiah peserta didik. Handout yang disusun guru terdiri dari uraian materi, namun kurang dilengkapi dengan aneka gambar, skema, maupun tabel yang dapat mendukung penyajian materi. Pemanfaatan lingkungan sekitar sekolah sebagai sumber belajar dalam pembelajaran klasifikasi belum pernah dilakukan oleh guru.

Berdasarkan uraian tersebut, penelitian dan pengembangan ini dilakukan dengan tujuan menyajikan suatu produk berupa perangkat pembelajaran klasifikasi hewan berbasis guided inquiry dengan sumber belajar keanekaragaman serangga Kebun Teh Wonosari yang 
valid dan mengetahui keefektifan perangkat pembelajaran yang dikembangkan melalui penilaian sikap ilmiah, keterampilan proses sains, pemahaman konsep serta keterlaksanaan perangkat pembelajaran berbasis guided inquiry pada materi klasifikasi hewan dengan sumber belajar keanekaragaman serangga Kebun Teh Wonosari.

\section{Metode}

Metode yang digunakan dalam penelitian dan pengembangan ini menggunakan model 4D oleh Thiagarajan et al., (1974) yang terbagi menjadi tahap Define, Design, Develop, dan Disseminate. Namun, penelitian dan pengembangan dibatasi hingga tahap Develop. Tahap define dilakukan dengan menganalisis kebutuhan instruksional untuk pengembangan perangkat pembelajaran. Tahap design merupakan tahap untuk merancang prototype perangkat pembelajaran. Berikutnya, tahap develop bertujuan untuk memodifikasi perangkat pembelajaran. melalui evaluasi dan revisi. Desain uji coba terdiri dari uji perseorangan dan uji kelompok kecil. Uji perseorangan melibatkan validator yang terdiri dari seorang ahli perangkat pembelajaran, seorang ahli materi materi dan dua orang praktisi pendidikan. Uji kelompok kecil dilaksanakan pada 33 siswa kelas VII-D SMPN 3 Lawang.

Jenis data terdiri dari data kuantitatif yang diperoleh dari hasil penskoran instrumen penelitian dan data kualitatif berupa catatan komentar dan saran validator terhadap produk perangkat pembelajaran. Data yang diperoleh berupa data validitas perangkat pembelajaran yang diukur dengan lembar validasi perangkat pembelajaran. Data sikap ilmiah dan keterampilan proses diperoleh melalui hasil penskoran pada lembar observasi sikap ilmiah dan lembar observasi keterampilan proses. Data pemahaman konsep diperoleh melalui hasil tes pemahaman konsep dan soal pada LKS. Teknik analisis data merupakan analisis kuantitatif dan analisis kualitatif. Data dianalisis kuantitatif dengan persentase kemudian hasil persentase dianalisis kualitatif dengan kriteria. Tabel 1 berikut menjelaskan kriteria validitas perangkat pembelajaran.

Tabel 1. Kriteria Tingkat Kevalidan Perangkat Pembelajaran

\begin{tabular}{lll}
\hline Tingkat Pencapaian (\%) & Kriteria Kevalidan & Keterangan \\
\hline $86-100$ & Sangat valid & Sangat baik dengan revisi kecil \\
$71-85$ & Valid & Boleh digunakan dengan revisi sebagian \\
$56-70$ & Cukup valid & Boleh digunakan dengan revisi besar \\
$41-55$ & Kurang valid & Tidak boleh digunakan \\
$25-40$ & Tidak valid & Tidak boleh digunakan \\
\hline
\end{tabular}

(Sumber: Diadaptasi dari Akbar, 2013: 78)

Kriteria berupa sikap ilmiah, keterampilan proses, dan pemahaman konsep dijelaskan pada Tabel 2.

Tabel 2. Kriteria Sikap Ilmiah, Keterampilan Proses Sains, dan Pemahaman Konsep

\begin{tabular}{cll}
\hline No. & Rentang Skor Hasil Belajar (\%) & Kriteria Hasil Belajar \\
\hline 1. & $85.01 \leq \mathrm{x} \leq 100.00$ & Sangat Tinggi \\
2. & $70.01 \leq \mathrm{x} \leq 85.00$ & Tinggi \\
\hline 3. & $55.01 \leq \mathrm{x} \leq 70.00$ & Cukup \\
4. & $40.01 \leq \mathrm{x} \leq 55.00$ & Rendah \\
5. & $01.00 \leq \mathrm{x} \leq 40.00$ & Sangat rendah \\
\hline
\end{tabular}

(Sumber: dimodifikasi dari Rokhayati, 2010: 25) 
Kriteria keterlaksanaan perangkat pembelajaran berbasis guided inquiry tertera pada Tabel 3 berikut.

Tabel 3. Kriteria penilaian hasil keterlaksanaan perangkat pembelajaran berbasis guided inquiry

\begin{tabular}{ll}
\hline Tingkat Pencapaian (\%) & Kriteria \\
\hline $81-100$ & Sangat baik \\
$61-80$ & Baik \\
$41-60$ & Cukup \\
$21-40$ & Kurang \\
$<21$ & Sangat kurang \\
\hline \multicolumn{2}{l}{ (Sumber: adaptasi Arikunto \& Jabar, 2010:35) }
\end{tabular}

\section{Hasil dan Pembahasan}

Hasil pengembangan berupa produk perangkat pembelajaran berbasis guided inquiry yang terdiri dari silabus, Rencana Pelaksanaan Pembelajaran (RPP), bahan ajar berupa Lembar Kerja Siswa (LKS) dan handout serta instrumen penilaian. Hasil validasi dari uji perseorangan menunjukkan bahwa validitas perangkat pembelajaran sebesar 87,94\% dengan kriteria sangat valid. Validitas komponen perangkat pembelajaran tertera pada Tabel 4 berikut.

Tabel 4. Data Validitas Perangkat Pembelajaran

\begin{tabular}{|c|c|c|c|c|}
\hline $\begin{array}{l}\text { Komponen } \\
\text { Perangkat }\end{array}$ & Sub Komponen & $\begin{array}{l}\text { Rerata sub } \\
\text { Komponen (\%) }\end{array}$ & $\begin{array}{l}\text { Rerata setiap } \\
\text { komponen (\%) }\end{array}$ & Kriteria \\
\hline Silabus & - & 86,45 & 86,45 & $\begin{array}{l}\text { Sangat } \\
\text { Valid }\end{array}$ \\
\hline RPP & - & 88,23 & 88,23 & $\begin{array}{l}\text { Sangat } \\
\text { Valid }\end{array}$ \\
\hline Bahan Ajar & $\begin{array}{l}\text { LKS } \\
\text { Handout } \\
\text { Sikap Ilmiah }\end{array}$ & $\begin{array}{l}90,00 \\
88,23 \\
85,00\end{array}$ & 89,11 & $\begin{array}{l}\text { Sangat } \\
\text { Valid }\end{array}$ \\
\hline $\begin{array}{l}\text { Intrumen } \\
\text { Penilaian }\end{array}$ & $\begin{array}{l}\text { Keterampilan } \\
\text { Proses Sains } \\
\text { Pemahaman } \\
\text { Konsep }\end{array}$ & $\begin{array}{l}90,00 \\
89,00\end{array}$ & 88,00 & $\begin{array}{l}\text { Sangat } \\
\text { Valid }\end{array}$ \\
\hline Rerata Skor & & & 87,94 & $\begin{array}{l}\text { Sangat } \\
\text { Valid }\end{array}$ \\
\hline
\end{tabular}

Uji kelompok kecil dilaksanakan dengan tujuan untuk keefektifan perangkat pembelajara melalui penilaian sikap ilmiah, keterampilan proses sains, pemahaman konsep, dan keterlaksanaan perangkat pembelajaran. Pembelajaran guided inquiry dilaksanakan berdasarkan perangkat pembelajaran hasil pengembangan. Penilaian sikap ilmiah dan keterampilan proses diperoleh dari pengamatan oleh observer selama pembelajaran dengan berpedoman pada instrumen lembar observasi sikap ilmiah dan keterampilan proses. Penilaian pemahaman konsep diperoleh dari hasil tes pemahaman konsep dan LKS yang dikerjakan siswa. Data penilaian sikap ilmiah, proses sains, dan pemahaman konsep ditunjukkan pada Tabel 5 berikut. 
Tabel 5. Data Hasil Uji Coba Keefektifan Perangkat Pembelajaran melalui Sikap Ilmiah, Keterampilan Proses Sains, dan Pemahaman Konsep

\begin{tabular}{lll}
\hline Komponen Uji Coba Keefektifan & Rerata Nilai (\%) & Kriteria \\
\hline Sikap Ilmiah & 85,30 & Sangat Tinggi \\
Keterampilan Proses Sains & 81,93 & Tinggi \\
Pemahaman Konsep & 78,88 & Tinggi \\
Rerata Nilai (\%) & 82,03 & Tinggi \\
\hline
\end{tabular}

Tabel 5 menunjukkan bahwa sikap ilmiah, keterampilan proses sains, dan pemahaman konsep siswa masuk dalam kriteria tinggi yaitu 82,03\%. Hal tersebut menyatakan bahwa pembelajaran yang dilaksanakan sudah efektif. Keefektifan perangkat pembelajaran juga diketahui dari penilaian keterlaksanaan perangkat pembelajaran oleh observer melalui lembar observasi. Data yang dihasilkan menunjukkan kriteria sangat baik dengan rerata nilai sebesar 91,02\%.

Perangkat pembelajaran berbasis guided inquiry pada materi klasifikasi hewan yaitu pengembangan perangkat klasifikasi hewan yang dirancang ke dalam silabus dan RPP serta dilengkapi dengan handout, LKS dan instrumen penilaian dengan langkah pembelajaran yang direncanakan sesuai dengan sintaks guided inquiry yaitu (1) orientasi, (2) merumuskan masalah, (3) merumuskan hipotesis, (4) merancang percobaan, (5) mengumpulkan data atau eksperimen, (6) mengevaluasi hipotesis, dan (7) merumuskan simpulan. Instrumen untuk menilai validitas perangkat pembelajaran berupa lembar validasi perangkat pembelajaran.

Perangkat pembelajaran yang dihasilkan memiliki validitas sebesar $87,94 \%$ dengan kriteria sangat valid dan dapat digunakan dalam pembelajaran. Rerata validitas silabus sebesar $86,45 \%$ dengan kriteria sangat valid. Silabus yang dikembangkan mengacu pada prinsip pengembangan silabus. Menurut Akbar (2013: 31), prinsip dalam pengembangan silabus yaitu relevansi, sistematis, konsistensi, memadai, aktual, kontekstual, fleksibilitas, dan menyeluruh. Pengembangan silabus memuat komponen yang dinyatakan dalam Permendikbud RI Nomor 65 (2013) dengan penyesuaian antara lain identitas mata pelajaran, identitas sekolah, Kompetensi Inti (KI), Kompetensi Dasar (KD), Indikator Kompetensi (IK), materi pokok, pembelajaran, penilaian, alokasi waktu, dan sumber belajar.

KI yang dicantumkan dalam silabus disesuaikan dengan ketetapan dalam Permendikbud RI Nomor 68 Tahun 2013 yaitu KI 1 untuk sikap spiritual, KI 2 untuk sikap sosial, KI 3 untuk pengetahuan dan KI 4 untuk keterampilan. KD materi klasifikasi makhluk hidup dirumuskan menurut Permendikbud RI Nomor 68 yaitu menggunakan KD 1.1, 2.1, 3.3, dan 4.3. IK dikembangkan berdasarkan empat dimensi KD yang merepresentasikan sikap spiritual, sikap sosial, pengetahuan, dan keterampilan. Pembelajaran dalam penelitian ini menerapkan model guided inquiry karena memenuhi karakteristik pembelajaran pada Kurikulum 2013 (Permendikbud RI Nomor 65, 2013) dan dapat membantu siswa dalam mencapai kompetensi secara utuh dan lengkap pada ranah sikap, keterampilan, dan pengetahuan. Alokasi waktu dikembangkan sesuai dengan jumlah jam pelajaran dalam struktur kurikulum untuk jenjang SMP/MTs yaitu 40 menit (Permendikbud RI Nomor 65, 2013). Sumber belajar utama dalam silabus menggali potensi alam keanekaragaman serangga di Kebun Teh Wonosari seperti dinyatakan Widowati (2012: 7), pemanfaatan lingkungan sekitar di dalam proses pembelajaran biologi akan lebih bermakna karena peserta didik 
dihadapkan pada peristiwa yang bersifat aktual dan alami yang dapat dipertanggungjawabkan kebenarannya.

RPP memiliki validitas sebesar 88,23\% dengan kriteria sangat valid. RPP yang disusun terdiri dari 3 pertemuan. Secara garis besar pertemuan pertama berisi tentang kegiatan awal yaitu orientasi, kemudian peserta didik membuat rumusan masalah dan hipotesis serta merancang percobaan yang akan dilakukan. pertemuan kedua berisi kegiatan pengamatan dan pengkalsifikasian serangga Kebun Teh Wonosari, pertemuan ketiga melanjutkan pengamatan serangga. RPP yang dikembangkan mengacu pada lampiran Peraturan Menteri Pendidikan dan Kebudayaan Nomor 103 Tahun 2014 tentang Pembelajaran Pendidikan Dasar dan Pendidikan Menengah.

Permendikbud RI Nomor 103 Tahun 2014 tentang penyusunan RPP memuat komponen RPP antara lain identitas sekolah/madrasah, mata pelajaran, dan kelas/semester, alokasi waktu, KI, KD, Indikator pencapaian kompetensi, materi pembelajaran, kegiatan pembelajaran, penilaian, media/alat, bahan, dan sumber belajar. Selain itu, pengembangan RPP juga memperhatikan prinsip penyusunan RPP menurut Permendikbud RI Nomor 103 Tahun 2014. RPP dikembangkan dari silabus dengan tambahan komponen berupa langkah pembelajaran. Pembelajaran dalam RPP dilakukan melalui tahapan pendahuluan, inti, dan penutup berbasis guided inquiry. Pembelajaran guided inquiry menurut Sanjaya (2011: 197) dimulai dari orientasi, merumuskan masalah, merumuskan hipotesis, merancang percobaan, mengumpulkan data atau eksperimen, mengevaluasi hipotesis, dan merumuskan simpulan.

Validitas bahan ajar yaitu $89,11 \%$ dengan kriteria sangat valid. Bahan ajar yang dikembangkan dalam penelitian ini merupakan jenis bahan ajar cetak antara lain LKS dan handout. Nilai validitas LKS klasifikasi Hewan hasil pengembangan sebesar 90\% dengan kriteria sangat valid. Guru tidak memberi tahu secara lengkap prosedur kerja dalam pengamatan klasifikasi hewan, sehingga setelah pengamatan dilakukan peserta didik dapat menemukan suatu konsep bagaimana cara melakukan klasifikasi. Hal tersebut sesuai dengan pernyataan Indriyani (2013: 14), bahwa LKS dapat membantu guru dalam memudahkan proses belajar mengajar dan mengarahkan peserta didiknya untuk dapat menemukan konsep melalui aktivitasnya sendiri dalam kelompok kerja.

Komponen LKS memuat identitas, serta petunjuk dan hasil pengamatan. Identitas berfungsi untuk menampilkan nama anggota kelompok siswa, serta petunjuk dan hasil pengamatan sebagai pedoman bagi siswa dalam melaksanakan kegiatan pembelajaran. Petunjuk dan hasil pengamatan disusun berdasarkan langkah guided inquiry dengan tujuan untuk membantu siswa memperoleh kompetensinya melalui observasi di Kebun Teh Wonosari.

Nilai validitas handout klasifikasi hewan hasil pengembangan sebesar 88,23\% dengan kriteria valid. Handout yang dikembangkan berisi informasi yang berkaitan dengan materi klasifikasi hewan disusun dari beberapa literatur, dengan tujuan memperkaya pengetahuan peserta didik sesuai dengan pernyataan Majid (2008). Handout dengan materi klasifikasi hewan yang sesuai dengan tingkat pengetahuan peserta didik. Handout disusun menjadi bagian sampul, dan uraian materi. Sampul berguna sebagai identitas handout, uraian materi klasifikasi hewan dikembangkan berdasarkan KD 3.3. Konsep disusun secara sistematis dan didukung dengan penyajian gambar, skema, dan tabel yang relevan. 
Penilaian hasil belajar menurut Permendikbud RI Nomor 66 Tahun 2013 mencakup kompetensi sikap, keterampilan, dan pengetahuan. Hasil penilaian diperoleh melalui instrumen penilaian yang berfungsi sebagai alat untuk mengumpulkan informasi tentang hasil belajar siswa. Rerata validitas instrumen penilaian menunjukkan kriteria sangat valid dengan nilai sebesar $89,11 \%$.

Validitas instrumen penilaian bernilai tinggi karena dikembangkan sesuai dengan kompetensi siswa yang diukur melalui pembelajaran berbasis guided inquiry. Menurut Suwono (2009), instrumen penilaian yang lengkap yaitu dapat digunakan untuk mengukur kompetensi sikap, keterampilan, dan pengetahuan. Selain itu, instrumen penilaian dinilai berdasarkan aspek materi, konstruksi, dan bahasa. Hal ini sejalan dengan persyaratan instrumen penilaian yang tercantum dalam Permendikbud RI Nomor 66 Tahun 2013 antara lain, substansi yang merepresentasikan kompetensi yang dinilai, konstruksi yang memenuhi persyaratan teknis, dan penggunaan bahasa yang baik, benar, dan komunikatif.

Keefektifan perangkat pembelajaran dilihat dari penilaian sikap ilmiah, keterampilan proses sains, pemahaman konsep peserta didik dan penilaian keterlaksanaan pembelajaran guided inquiry. Hasil uji coba produk perangkat pembelajaran terhadap sikap ilmiah menunjukkan rerata kelas tingkat sikap ilmiah peserta didik adalah 85,30\%. Nilai rerata ini termasuk dalam kategori sangat tinggi. Hal tersebut dikarenakan siswa antusias dalam melakukan tiap tahap guided inquiry. Keterlibatan siswa dalam tiap tahap guided inquiry ini memberikan pengalaman bagi siswa. Menurut Anwar (2009) sikap timbul melalui pengalaman dan tidak dibawa sejak lahir sehingga sikap dapat diperteguh atau diubah melalui proses belajar. Sikap ilmiah harus ada pada diri seorang ilmuwan atau akademisi ketika menghadapi persoalan ilmiah, sehingga membiasakan peserta didik untuk memberikan respons atau tingkah laku seperti rasa ingin tahu, bekerja sama, terbuka, bekerja keras, jujur, disiplin, peduli, dan bertanggung jawab ketika sedang menghadapi persoalan atau melakukan penelitian ilmiah.

Sikap ilmiah terfasilitasi pada sintaks guided inquiry antara lain pada sintaks orientasi yaitu mengembangkan rasa ingin tahu, kemudian sintaks pengumpulan data dan evaluasi hipotesis dapat mengembangkan sikap jujur, tekun, teliti, dan bertanggung jawab. Sikap jujur dinilai dari cara pemerolehan data yang sesuai dengan hasil pengamatan, tekun dinilai dari sikap tidak gampang menyerah saat melakukan pengamatan, teliti dinilai dari kebenaran pengumpulan dan penganalisisan data, tanggung jawab dinilai atas data yang diperoleh dan peralatan yang digunakan saat pengamatan.

Keterampilan proses menurut Ango (2002) merupakan keterampilan untuk mengobservasi, menanya, melakukan eksperimen, mengorganisasi, menginterpretasi data, dan mengkomunikasikan. Nilai keterampilan proses siswa sebesar 81,93\% dengan kategori tinggi. Hal tersebut dikarenakan siswa antusias dalam melakukan tiap tahap guided inquiry.

Keterampilan proses sains terfasilitasi pada sintaks guided inquiry antara lain pada sintaks merumuskan masalah, merumuskan hipotesis, dan pengumpulan data. Dalam keterampilan merumuskan masalah siswa mengamati berbagai gambar yang disediakan guru, siswa membuat pertanyaan dari apa yang mereka amati kemudian memprediksi jawaban dari pertanyaan tersebut. Pada sintaks pengumpulan data dapat menilai indikator keterampilan proses yaitu keterampilan menerapkan prosedur pengklasifikasian makhluk 
hidup, keterampilan mengklasifikasikan hewan serangga yang ditemukan, dan keterampilan mengumpulkan data klasifikasi hewan serangga.

Keterampilan proses dalam guided inquiry beriringan dengan sikap ilmiah. Pembelajaran berbasis guided inquiry pada akhirnya dapat menjadi sarana untuk melatihkan sikap ilmiah dan keterampilan proses siswa karena ada keterpaduan diantara langkah guided inquiry dengan dimensi sikap ilmiah dan keterampilan proses. Kompetensi berupa sikap ilmiah dan keterampilan proses siswa yang dilatihkan melalui pembelajaran berbasis guided inquiry akan menuntun siswa menemukan dan memahami suatu konsep. Hal ini didukung oleh pernyataan Anwar et al., (2012) bahwa keterampilan proses akan menjadi roda penggerak penemuan dan pengembangan fakta dan konsep serta pertumbuhan dan pengembangan sikap dan nilai.

Pernyataan tersebut dibuktikan pada nilai tes pemahaman konsep klasifikasi hewan yang diperoleh dari hasil tes menunjukkan nilai 78,88\% dengan kategori tinggi. Hal ini disebabkan karena sikap ilmiah dan keterampilan proses yang diperoleh siswa melalui pembelajaran guided inquiry telah menuntun siswa memperoleh pemahaman konsep yang baik. Penelitian yang dilakukan Martiana (2014) menunjukkan bahwa pembelajaran IPA biologi dengan menggunakan metode guided inquiry dapat meningkatkan pemahaman konsep siswa.

Nilai keterlaksanaan perangkat pembelajaran dari hasil observasi sebesar 91,02\% termasuk dalam kategori sangat baik. Hal tersebut dikarenakan tiap tahap pembelajaran berbasis guided inquiry dilaksanakan dengan baik dan pemanfaatan sumber belajar maksimal. Dampak dari keterlaksanaan perangkat pembelajaran yang diterapkan adalah siswa antusias dalam melaksanakan pembelajaran karena siswa dilibatkan dalam pengamatan di lingkungan. Widowati (2012) menyatakan bahwa dalam belajar siswa tidak sekedar melakukan pengamatan tetapi harus terlibat langsung dalam kegiatan untuk pemerolehan pengetahuan, pembentukan sikap dan keterampilan. Nurdiana et al., (2014) menjelaskan bahwa pemanfaatan lingkungan sekolah sebagai sumber belajar akan memacu aktivitas dan motivasi siswa dalam pembelajaran. Adanya keterlibatan siswa akan membangkitkan keingintahuan siswa dalam memahami materi sehingga hasil belajar siswa meningkat.

Chodijah et al. (2012) dalam penelitiannya menyatakan berdasarkan keefektifan pembelajaran dengan melihat kecermatan penguasaan perilaku yang dipelajari peserta didik, maka perangkat pembelajaran yang digunakan dalam penelitian memiliki dampak ketika digunakan dalam proses pembelajaran, sehingga hasil efektivitas terlihat pada aktivitas peserta didik yang mencakup aspek kognitif, afektif dan psikomotor. Hal tersebut dianalogikan untuk mengetahui keefektifan perangkat pembelajaran berbasis guided iquiry yaitu dengan melihat hasil penilaian sikap ilmiah, keterampiln proses sains, dan pemahaman konsep.

Pembelajaran klasifikasi hewan berbasis guided inquiry dengan sumber belajar Kebun Teh Wonosari memberikan kesempatan bagi peserta didik untuk menemukan sendiri konsep yang dipelajari dengan melakukan kegiatan pengamatan. Peserta didik terlibat langsung dalam pembelajaran yang dilakukan, dimana selama kegiatan pengamatan peserta didik diberikan kesempatan untuk mengembangkan sikap ilmiah keterampilan proses sains dan pemahaman konsep. Peserta didik dapat menemukan konsep klasifikasi ketika peserta didik 
melakukan pengamatan ciri serangga di area Kebun Teh Wonosari dan mengorganisasikan ciri setiap serangga yang ditangkap dalam tabel, sehingga tampak adanya persamaan dan perbedaan. Persamaan ciri antar serangga yang diamati yang selanjutnya digunakan peserta didik dalam membuat pengelompokan. Pembelajaran guided inquiry akan meningkatkan keterampilan proses dan sikap ilmiah yang dimiliki siswa hingga terbentuk konsep dalam pikiran siswa.

\section{Simpulan}

Berdasarkan pembahasan dapat disimpulkan telah dihasilkan perangkat pembelajaran yang memiliki kriteria validitas yang sangat valid, kompetensi peserta didik yang meliputi sikap ilmiah, keterampilan proses, dan pemahaman konsep menunjukkan kriteria tinggi. Hasil penelitian dan pengembangan menunjukkan bahwa perangkat pembelajaran dapat digunakan dalam pembelajaran dan dapat membantu peseta didik memiliki sikap ilmiah, keterampilan proses sains, dan pemahaman konsep. Saran yang diberikan antara lain penyebarluasan perangkat pembelajaran klasifikasi hewan perlu dilakukan untuk kelas yang lain dan bahkan sekolah lain. Lembar validasi perangkat pembelajaran sebaiknya diberi intruksi yang jelas maka validator dapat memberikan keterangan perbaikan pada setiap aspek yang dikaji. Perangkat pembelajaran yang dikembangkan sebaiknya dieksperimenkan untuk mengetahui pengaruhnya dengan perangkat pembelajaran yang biasanya disusun oleh guru tanpa memanfaatkan sumber belajar di sekitar peserta didik

\section{Daftar Rujukan}

Akbar, S. D. (2013). Instrumen perangkat pembelajaran.

Ango, M. L. (2002). Mastery of Science Process Skills and Their Effective Use in the Teaching of Science: An Educology of Science Education in the Nigerian Context. Online Submission, 16(1), 11-30.

Anwar, M., \& Sugiharto, D. Y. P. (2012). Pengembangan Perangkat Pembelajaran Biologi Dengan Pendekatan Bioenterpreneurship Untuk Meningkatkan Keterampilan Proses Ilmiah Dan Minat Berwirausaha Siswa. Innovative Journal of Curriculum and Educational Technology, 1(1).

Arikunto, S., \& Jabar, C. S. A. (2004). Evaluasi program pendidikan pedoman teoritis praktis bagi praktisi Pendidikan. Jakarta: Bumi Aksara.

Chodijah, S., Fauzi, A., \& Ratnawulan, R. (2012). Pengembangan perangkat pembelajaran fisika menggunakan model guided inquiryyang dilengkapi penilaian portofolio pada materi gerak melingkar. Jurnal Penelitian Pembelajaran Fisika, 1(1).

Fakhruddin, Z., Eprina, E., \& Syahril, S. (2010). Sikap Ilmiah Siswa Dalam Pembelajaran Fisika Dengan Penggunaan Media Komputer Melalui Model Kooperatif Tipe Stad Pada Siswa Kelas X3 Sma Negeri I Bangkinang Barat. Jurnal Geliga Sains: Jurnal Pendidikan Fisika, 4(1).

Indriyani, I. R. (2013). Pengembangan LKS Fisika Berbasis Siklus Belajar (Learning Cycle) 7E Untuk Meningkatkan Hasil Belajar dan Mengembangkan Kemampuan Berpikir Kritis Pada Siswa SMA Kelas X Pokok Bahasan Elektromagnetik. The Official UAD Scientific Journal. Tersedia di http://journal. uad. ac. id/index. php/index/index.[diakses 22-2-2013].

Kartono. (2012). Pengembangan Model Penilaian Sikap Ilmiah IPA Bagi Mahasiswa PGSD. (Online), (https://eprints.uns.ac.id/15202/1/Publikasi_Jurnal_(37).pdf), [diakses 8 September 2015].

Lailiyah, S. (2007). Pengaruh penggunaan pendekatan inqoury terhadap kemampuan psikomotorik ditinjau dari kemampuan kognitif mahasiswa jurusan pmipa FKIP UNS tahun ajaran 2006/2007.

Majid, A. (2008). Perencanaan pembelajaran mengembangkan standar kompetensi guru. Bandung: PT Remaja Rosdakarya.

Martiana, C. (2014). Pengembangan perangkat pembelajaran klasifikasi tumbuhan berbasis discoveryinquiry dengan sumber belajar Kebun Raya Purwodadi untuk siswa kelas VII SMP Negeri 1 Purwosari (Doctoral dissertation, Universitas Negeri Malang). 
Nurdiana, F. R. (2014). Pengembangan perangkat pembelajaran ekosistem berbasis discovery-inquiry dengan sumber belajar pantai Lekok sebagai sarana mengembangkan sikap ilmiah, keterampilan proses sains, dan pemahaman konsep siswa kelas VII SMPN 1 Lekok. SKRIPSI Jurusan Biologi-Fakultas MIPA UM.

Pendidikan, B. S. N., \& Indonesia, K. R. (2013). Standar Proses Pendidikan Dasar dan Menengah. Peraturan Menteri Pendidikan dan Kebudayaan Nomor, 65.

Pendidikan, M. (2014). Peraturan Menteri Pendidikan dan Kebudayaan Republik Indonesia Nomor 103 Tahun 2014 Tentang Pembelajaran pada Pendidikan Dasar dan Pendidikan Menengah. Tersedia: www. dikmen. kemdikbud. go. id/kurikulum2013/.[Januari 2015].

Sanjaya, W. (2019). Strategi pembelajaran berorientasi standar proses pendidikan.

Suwono, H. (2009). Dasar-dasar Penilaian Hasil Belajar IPA. Surabaya: Putra Media Nusantara.

Thiagarajan, S. (1974). Instructional development for training teachers of exceptional children: A sourcebook.

Widowati, A. (2012). Optimalisasi Potensi Lokal Sekolah dalam Pembelajaran Biologi Berbasis Kontruktivisme. Majalah Ilmiah Pembelajaran, 8(2).

Wijayanti, A. (2010). Peningkatan Pemahaman Konsep Prosedur Pengelasan Las Listrik Melalui Pendekatan Pembelajaran Aktif Inovatif Kreatif Efektif dan Menyenangkan (Paikem) Siswa Kelas X SMK Negeri 5 Surakarta Tahun Ajaran 2009/2010. 